\title{
PENGARUH SELF-EFFICACY TERHADAP PRESTASI BELAJAR IPS SISWA KELAS VIII SMP
}

\author{
Diaz Ayu Sudwiarrum ${ }^{1}$, Nuryana ${ }^{2}$, Ratna Puspitasari ${ }^{3}$ \\ IAIN Syekh Nurjati Cirebon \\ diazayu@syekhnurjati.ac.id; nuryana@syekhnurjati.ac.id; \\ ratnapuspitasari@syekhnurjati.ac.id
}

\begin{abstract}
ABSTRAK
Penelitian ini bertujuan untuk mengetahui bagaimana tingkat self-efficacy siswa, prestasi belajar siswa, dan mengetahui seberapa besar pengaruh self-efficacy siswa kelas VIII SMP Negeri 2 Sumber Kabupaten Cirebon. Self-efficacy adalah keyakinan akan kemampuan seseorang untuk mengatur dan melakukan kegiatan yang diharapkan untuk mencapai tujuan yang telah ditetapkan. Prestasi belajar merupakan akibat dari sistem pembelajaran dalam jangka waktu tertentu yang diakui ke dalam nilai-nilai berupa angka dan huruf. Semakin baik self-efficacy siswa, semakin baik pula pencapaian prestasi belajar siswa tersebut, begitu pula sebaliknya. Penelitian ini merupakan penelitian kuantitatif. Konfigurasi eksplorasi ini menggunakan dua kumpulan faktor, yaitu variabel $\mathrm{X}$ (self-efficacy) dan variabel Y (Prestasi Belajar). Populasi penelitian adalah seluruh siswa kelas VIII di SMP Negeri 2 Sumber Kabupaten Cirebon berjumlah 246 siswa yang dipilih secara random sampling. Teknik pengumpulan data dalam penelitian ini menggunakan angket dan studi dokumentasi. Teknik analisis data menggunakan regresi linier sederhana. Hasil dari penelitian ini menunjukkan bahwa: (1) tingkat self-efficacy siswa 69,18\% termasuk dalam kategori cukup baik, (2) tingkat prestasi siswa $79,21 \%$ termasuk dalam kategori baik, (3) nilai sig. 0,000, dengan alasan bahwa 0,000<0,05 maka Ho ditolak dan Ha diakui bahwa ada pengaruh self-efficacy terhadap prestasi belajar, (4) koefisien determinasi (R2) 0,524 menunjukkan bahwa tingkat komitmen dampak variabel otonom sebesar 52,4\%. Hal ini menunjukkan bahwa 52,4\% prestasi belajar dipengaruhi oleh self-efficacy, sedangkan 47,6\% dipengaruhi oleh unsur yang berbeda.
\end{abstract}

Kata Kunci: Prestasi Belajar, Self-Efficacy

\begin{abstract}
This study aims to find out how the level of student self-efficacy, student achievement, and find out how much influence self-efficacy of class VIII students of SMP Negeri 2 Sumber Cirebon Regency has. Self-efficacy is the belief in one's ability to organize and carry out activities that are expected to achieve the goals that have been set. Learning achievement is the result of a learning system within a certain period of time which is recognized in values in the form of numbers and letters. The better the student's self-efficacy, the better the student's learning achievement, and vice versa. This research is a quantitative research. This exploratory configuration uses two sets of factors, namely variable $X$ (selfefficacy) and variable $Y$ (Learning Achievement). The research population was all students of class VIII at SMP Negeri 2 Sumber Cirebon, totaling 246 students who were selected by random sampling. Data collection techniques in this study used questionnaires and documentation studies. The data analysis technique used simple linear regression. The results of this study indicate that: (1) the self-efficacy level of students $69.18 \%$ is included in the fairly good category, (2) the student achievement level is $79.21 \%$ is included in the good category, (3) sig. 0.000, on the grounds that $0.000<0.05$ then Ho is rejected and Ha is accepted that there is an effect of self-efficacy on learning achievement, (4) the coefficient of
\end{abstract}

Jurnal Edueksos Vol. X, No. 2, Desember 2021

The journal of social and economic education 
determination ( $R 2) 0.524$ indicates that the level of commitment of the autonomous variable is $52.4 \%$. This shows that $52.4 \%$ of learning achievement is influenced by self-efficacy, while $47.6 \%$ is influenced by different elements.

Key Words: Learning Achievement, Self-Efficacy

\section{A. PENDAHULUAN}

Tujuan pendidikan seperti yang ditunjukkan oleh UNESCO (United Nations Educational Scientific and Cultural Organization) adalah dua standar pendidikan yang dipandang sebagai tujuan informatif yang komprehensif, khususnya pembelajaran sepanjang hayat, dan pilar sekolah yang harus bergantung pada mencari tahu bagaimana mengetahui, belajar melakukan, mencari tahu dan menemukan perilaku yang dapat diterima secara normal, serta belajar bersama (Martinez \& Stager, 2013).

Mengingat gambaran di atas, salah satu tujuan sekolah adalah untuk mengetahui bagaimana bertindak secara alami. Mencari tahu bagaimana bertindak secara alami diidentifikasikan dengan keyakinan diri dan kepercayaan diri. Seorang individu yang memiliki keyakinan pada dirinya sendiri akan melihat nilai dalam setiap batas yang dihindari (Schmoker, 2018). Pada dasarnya, manusia adalah mahkluk yang berpikir, mereka biasanya ingin mengetahui sesuatu yang hebat tentang diri mereka sendiri dan keadaan mereka saat ini melalui lima deteksi yang mereka miliki sesuai dengan peningkatan usia mereka. Setiap individu akan menjadi dewasa karena pembelajaran dan pengalaman yang dialami selama hidupnya (Rijal \& Bachtiar, 2015).

Keberanian juga disebut kecukupan diri. Menurut Jeanne Ellis Omrod, selfefficacy adalah keyakinan individu tentang kapasitasnya sendiri untuk menyelesaikan praktik tertentu dan tujuan tertentu (Hardianto et al., 2014). Mengingat penilaian ini, dapat dikatakan bahwa kelangsungan hidup diri sendiri secara tegas diidentifikasikan dengan percaya diri. Siswa yang memiliki selfefficacy yang tinggi akan memiliki kepercayaan diri yang tinggi pula. Siswa akan memiliki pandangan yang mahir dan pasti tentang hal-hal yang mereka lakukan. 
Seperti yang ditunjukkan oleh teori kognitif sosial Bandura, selfefficacy memengaruhi keputusan individu dalam membuat dan menyelesaikan gerakan yang mereka buat. Orang-orang fokus pada usaha yang tidak bisa mereka lakukan. Kelangsungan hidup juga membantu dengan seberapa banyak usaha yang akan mereka lakukan, berapa lama mereka akan menghadapi rintangan, dan seberapa tangguh mereka meskipun ada sesuatu yang tidak sesuai (Mukhid, 2009).

Seseorang dengan self-efficacy yang tinggi menerima bahwa mereka dapat secara efektif mengubah situasi, sementara seseorang dengan self-efficacy yang rendah memandang dirinya pada dasarnya tidak mampu melakukan segala sesuatu disekitarnya (Ghufron \& Risnawati, 2016). Dilihat dari penilaian yang disampaikan oleh para ahli, dapat dikatakan bahwa self-efficacy memegang peranan pentingn karena realitasnya akan memacu individu untuk memiliki konsistensi yang lebih besar sebagai bentuk pengaturan diri dalam menghadapi kesulitan untuk mencapai tujuan yang telah ditetapkan. Masa-masa peningkatan kemampuan diri tersebut dipisahkan menjadi beberapa fase, sejak manusia dikandung, kemudian pada saat itulah kecukupan diri menuju awal perkembangan, pada masa muda, remaja, dewasa, hingga usia lanjut (Marini \& Hamidah, 2014). Self-efficacy dan kecenderungan belajar merupakan faktor mental sehingga variabel-variabel ini juga berpengaruh dalam menentukan prestasi belajar. Kelangsungan hidup berjalan sebagai pendorong, sementara berkonsentrasi pada kecenderungan adalah teknik untuk mendapatkan prestasi belajar yang luar biasa (Rosyida et al., 2016).

Penelitian Janatin (2015) mengenai Hubungan antara Self-Efficacy dengan Prestasi Belajar Siswa Kelas IV SD Se-Gugus II Kecamatan Bantul Tahun Ajaran 2014/2015. Dalam jurnal tersebut menunjukkan bahwa terdapat hubungan yang positif dan signifikan antara self-efficacy dengan prestasi belajar siswa kelas IV SD se-Gugus II Kecamatan Bantul tahun ajaran 2014/2015 dengan nilai Pearson Correlation pada SPPS sebesar 0,7233 dan nilai $\mathrm{P} 0,00<0,05$ 
yang menunjukkan adanya hubungan yang positif dan signifikan. Dalam Pertiwi (2015) mengenai Pengaruh Self-Efficacy terhadap Hasil Belajar pada Siswa Kelas V Sekolah Dasar Daerah Binaan IV Kecamatan Cilacap Selatan Kabupaten Cilacap. Penelitian tersebut menunjukkan bahwa terdapat pengaruh yang signifikan self-efficacy terhadap hasil belajar siswa dengan koefisiensi determinasi sebesar 29,6\%. Adapum penelitian yang dilakukan oleh Sholichah (2017) mengenai Pengaruh Self-Efficacy terhadap Hasil Belajar Matematika Siswa Kelas $\quad$ VII MTs Darussalam Kademangan Blitar Tahun Ajaran 2016/2017. Dalam penelitian tersebut menunjukkan bahwa terdapat pengaruh yang signifikan antara selfefficacy terhadap hasil belajar siswa dengan $r_{\text {hitung }}=0,612>r_{\text {tabel }}=0,349$ dengan koefisiensi determinasi sebesar 37,4\%.

Berdasarkan beberapa kajian di atas, cenderung terlihat bahwa self-efficacy menjadi sesuatu yang vital dalam kehidupan seseorang karena selfefficacy dapat mempengaruhi berbagai hal dalam kehidupan sehari-hari, terutama bagi yang masih dalam tahap perbaikan, terutama prestasi siswa.

Pentingnya self-efficacy terlihat dimana siswa yang cerdas mereka akan selalu mendapatkan nilai kelulusan, begitu juga sebaliknya. Namun, siswa yang cerdas tidak benar-benar mendapatkan prestasi belajar yang menyenangkan, seperti yang diungkapkan bahwa belajar tidak hanya dipengaruhi oleh tingkat pemahaman siswa, tetapi belajar dipengaruhi oleh banyak variabel. Jika unsurunsur tersebut merusak siswa, maka akan mempengaruhi prestasi belajar mereka (Pratesi, 2018). Dimana prestasi belajar merupakan penggambaran dari dominasi yang tidak benar-benar diatur untuk ilustrasi tertentu. Prestasi belajar dihubungkan dengan nilai tes sehubungan dengan sejumlah topik tertentu (Rosyid et al., 2019). Individu yang memiliki self-efficacy yang tinggi umumnya akan memiliki kerja yang luar biasa untuk mengatasi hambatan dalam mencapai tujuan. Itulah sebabnya siswa yang memiliki self-efficacy tinggi akan lebih siap untuk memutuskan profesi yang tepat bagi dirinya (Adnyana \& Purnami, 2016). 
Demikian halnya self-efficacy yang dimiliki siswa SMP Negeri 2 Sumber, Kabupaten Cirebon. Setelah pendidik melakukan penelitian awal, terlihat bahwa pendidik telah berusaha untuk menanamkan self-efficacy pada siswa, dengan harapan mereka akan berkembang dengan baik sehingga sangat mempengaruhi prestasi belajar. Sebagian dari upaya yang dilakukan oleh pendidik mengingat memberikan inspirasi pada jenis kata yang dapat mendorong kegembiraan dan kepercayaan siswa pada kemampuan mereka dalam belajar, instruktur juga berupaya untuk mengembangkan model pembelajaran fokus siswa (Amanda et al., 2014).

Prestasi belajar merupakan konsekuensi dari interaksi belajar individu. Prestasi belajar diidentikkan dengan perubahan pada individu yang belajar. Jenis kemajuan karena belajar adalah sebagai perubahan informasi, mendapatkan, cara pandang dan perilaku, kemampuan dan kapasitas. Perubahan perasaan perubahan yang dibawa oleh pembangunan tidak dianggap sebagai hasil belajar. Perubahan karena belajar umumnya tahan lama dan mungkin bisa menciptakan (Rosyid et al., 2019). Prestasi belajar adalah otoritas informasi dan kemampuan yang diciptakan dan diperoleh melalui siklus bisnis siswa dalam kolaborasi dinamis subjek dengan iklim yang dapat dilihat dari prestasi belajar IPS siswa (Sirait, 2016). Dalam penjelasan lain dikatakan bahwa prestasi belajar adalah suatu karya atau tindakan anak untuk mendominasi materi pembelajaran yang diberikan oleh pengajar di sekolah. Prestasi belajar adalah istilah yang telah dicapai seseorang sebagai suatu karya yang dapat langsung (Wijayani et al., 2017).

Self-efficacy juga berperan penting dalam mengembangkan prestasi belajar siswa, memang apa yang terjadi dalam ranah prestasi belajar mengajar tidak mencukupi karena banyak siswa yang masih sakit dalam ketidakberdayaan, tidak yakin akan kemampuan mereka atau hanya pasrah pada nasib mereka.

Beberapa siswa memiliki masalah, baik masalah akademik (prestasi belajar) dan masalah perilaku siswa yang mencakup kemampuan untuk mengendalikan diri, inspirasi diri, perlindungan dari ketidakpuasan, mengelola temperamen, kemampuan untuk menunjukkan watak, kurang siap untuk mengendalikan 
perasaan seperti ketenangan. dalam hubungan dengan teman mereka dan tidak adanya simpati untuk teman (Hulu \& Minauli, 2013).

Kebenaran di lapangan berada dalam kondisi yang berbeda-beda, antara lain perasaan tidak menentu terhadap kapasitas yang ditemukan dan tidak adanya keterbukaan diri. Hal ini dapat dilihat ketika pendidik mengajukan siswa untuk menjawab pertanyaan, siswa akan lebih sering tidak terlibat dan tidak memiliki keinginan untuk menjawab pertanyaan dari guru. Ada juga siswa yang melakukan apa saja untuk tidak melakukan tugas yang diberikan oleh pengajar. Siswa menunjukkan dan mengatakan tugas yang diberikan terlalu merepotkan. Mereka tidak berusaha untuk menaklukkan tantangan yang dialami. Selain itu, siswa juga masih segar dan mempertimbangkan mereka secara mandiri selama tes di kelas. Hal ini terlihat ketika siswa berusaha untuk berbicara dan bermain dengan temannya ketika pembelajaran berlangsung secara konsisten (Hari et al., 2018).

Beberapa siswa juga menerima bahwa nilai kelulusan didapat dengan asumsi mereka pintar, begitu juga sebaliknya, jika mereka tidak pintar, mereka akan selalu mendapatkan nilai jelek (Yoannita et al., 2016). Setelah mendapatkan skor yang tidak dapat diterima lebih dari satu kali, mereka akan merasakan di masa depan mereka akan mendapatkan skor yang tidak dapat diterima juga. Ini karena setelah beberapa kali mendapatkan nilai yang tidak dapat diterima, mereka diyakinkan bahwa mereka tidak dapat mengerjakan soal-soal ujian karena ketidakmampuan mereka. Inspirasi mereka berkurang karena mereka gagal beberapa kali selama tes. Hal serupa juga terjadi pada prestasi belajar siswa yang masih rendah dibandingkan dengan Kriteria Ketuntasan Minimum (KKM).

Berdasarkan hal tersebut, penelitian ini bertujuan untuk menentukan selfefficacy siswa kelas VIII SMP Negeri 2 Sumber Kabupaten Cirebon, untuk $\begin{array}{llllll}\text { menentukan prestasi belajar IPS siswa kelas VIII SMP Negeri } 2 & 2\end{array}$ Sumber Kabupaten Cirebon, dan untuk mengetahui pengaruh self-efficacy terhadap prestasi belajar IPS siswa kelas VIII SMP Negeri 2 Sumber Kabupaten Cirebon. 


\section{B. METODE PENELITIAN}

Penelitian ini merupakan tinjauan kuantitatif menggunakan uji statistika dengan regresi linier sederhana. Desain penelitian ini menggunakan dua kumpulan faktor, yaitu variabel spesifik X (self-efficacy) dan variabel Y (prestasi belajar). Populasi keseluruhan adalah seluruh siswa kelas VIII di SMP Negeri 2 Sumber Kabupaten Cirebon sebanyak 246 siswa yang tersebar lebih dari tujuh kelas. Tes ini menggunakan prosedur pemeriksaan secara acak dengan alasan bahwa individu-individu dari populasi dipandang sebagai homogen atau tidak didefinisikan dan populasi ini tidak terlalu besar. Oleh karena itu, peneliti mengambil sampel $25 \%$ dari populasi sehingga jumlah tes dalam audit ini adalah $246 \times 25 \%=60$ siswa.

Strategi pengumpulan informasi dalam tinjauan ini menggunakan angket dan studi dokumentasi. Instrumen yang digunakan dalam angket ini adalah skala kecukupan diri yang merupakan skala mental dengan skala Likert yang memiliki empat pilihan jawaban, yaitu secara tegas setuju (SS), setuju (S), menyimpang (TS), tegas tidak setuju (STS) dengan memberi skor 1-4. Hal-hal penegasan dalam angket self-efficacy dibuat tergantung indikator yang dikembangkan pada tiga komponen self-efficacy Bandura dalam Ghufron (2016), secara spesifik tingkat kesulitan (level), tingkat solidaritas (kekuatan), dan spekulasi (konsensus). Pengambilan prestasi belajar IPS diperoleh dari hasil akademik siswa yang dituangkan dalam bentuk kualitas atau angka yang tercatat dalam nilai rapor IPS semester ganjil tahun pelajaran 2018/2019..

\section{HASIL DAN PEMBAHASAN}

Pembahasan dalam penelitian ini tergantung pada penyebaran angket dan intepretasi pengolahan data yang diperoleh dari hasil untuk memutuskan hasil yang digunakan dan tujuan pemeriksaan tergantung pada teori yang digunakan. Self-efficacy tergantung pada indikator yang dibuat tergantung pada tiga komponen self-efficacy. Sementara itu, prestasi belajar IPS diperoleh dari pengambilan hasil kognittif siswa yang diperoleh dari struktur atau angka yang 
tercatat dalam laporan prestasi belajar IPS semester ganjil tahun pelajaran 2018/2019. Hasil pemeriksaan dapat dirinci sebagai berikut :

\section{Self-efficacy siswa kelas VIII SMP Negeri 2 Sumber Kabupaten Cirebon}

Hasil Berdasarkan penelitian tersebut, dapat diketahui bahwa siswa SMP Negeri 2 Sumber Kabupaten Cirebon memiliki self-efficacy dalam klasifikasi sangat baik. Hal ini ditunjukkan dengan terpenuhinya ukuran kecukupan diri yang diklaim oleh siswa sebagaimana ditunjukkan oleh pernyataan responden sebesar $69,18 \%$ pada rentang waktu $75 \%$. Secara angka memang capaian tersebut tampak kurang optimal, namun jika dilihat dari segi apa yang dipandang sebagai energi positif, sesungguhnya merupakan komponen pendukung yang berbeda bagi tercapainya suatu interaksi belajar.

Dalam realitas menunjukkan bahwa sebagian besar siswa kelas VIII SMP Negeri 2 Sumber Kabupaten Cirebon percaya akan kemampuannya. Siswa merasa siap untuk menyelesaikan tugas yang sulit, yakin dengan kemampuan mereka dan merasa siap untuk melakukan tugas dalam latihan dan situasi yang berbeda. Berdasarkan hasil pengamatan, beberapa kendala atau hambatan ditemukan dalam menyelesaikan tugas namun siswa memiliki pilihan untuk mengatasinya, misalnya ketika siswa mengalami hambatan atau kesulitan dalam tugas mereka, siswa tidak dengan mudah menyerah dan meningkatkan upaya mereka untuk memiliki pilihan untuk mengalahkan penghalang tersebut.

Memiliki kepercayaan diri yang tinggi dibutuhkan oleh semua orang, akan sangat menarik dalam menyelesaikan tugas atau latihan yang diandalkan untuk mencapai hasil tertentu. Seorang individu dengan self-efficacy tinggi mengakui bahwa mereka dapat berhasil mengubah keadaan mereka, sementara seseorang dengan self-efficacy rendah merasa bahwa mereka secara umum tidak siap untuk melakukan segala sesuatu di sekitar mereka. Di tempat-tempat yang sulit, siswa dengan kepercayaan diri yang rendah akan sering menyerah tanpa masalah. Sementara itu, siswa dengan kepercayaan diri yang tinggi akan berkontribusi lebih banyak pekerjaan untuk mengatasi kesulitan ini. Hal yang 
sama juga disampaikan oleh Gist, yang menunjukkan bukti bahwa kemandirian berperan penting dalam mendorong buruh untuk menyelesaikan pekerjaan pindahan sesuai dengan pencapaian tujuan tertentu (Ghufron \& Risnawati, 2016).

Tinggi rendahnya kepercayaan siswa kelas VIII SMP Negeri 2 Sumber Kabupaten Cirebon dapat disebabkan oleh banyak faktor, mengingat banyak hal yang mempengaruhi kemandirian individu. Seperti yang ditunjukkan oleh Bandura (2003), daya tahan individu dapat diperoleh, dibuat, atau diturunkan melalui satu atau empat sumber, terutama pengalaman masa lalu (dominance experience), wawasan dari orang lain (vicarious experience), pengaruh sosial (social influence), serta keadaan fisik dan perasaan (kondisi fisiologis dan emosional).

\section{Prestasi belajar IPS siswa kelas VIII di SMP Negeri 2 Sumber Kabupaten} Cirebon

Berdasarkan hasil kajian, prestasi belajar IPS siswa kelas VIII di SMP Negeri 2 Sumber Kabupaten Cirebon berada pada taraf yang sangat baik, dilihat dari jumlah siswa yang dinyatakan tuntas melebihi KKM dengan nilai terbesar. dari 87, skor terkecil 74, dan skor biasa 79,21\%. Suryabrata (2002) berpendapat bahwa untuk menentukan prestasi belajar individu, mengevaluasi hasil bimbingan yang diberikan. Dalam audit ini, strategi penilaian prestasi belajar adalah dengan memanfaatkan tes hasil nilai rapor semester gasal tahun pelajaran 2018/2019. Nilai rata-rata nilai rapor siswa kelas VIII di SMP Negeri 2 Sumber Kabupaten Cirebon menunjukkan pengelompokan yang cukup baik yaitu berkisar antara 50-79\%.

Bire (2014) berpendapat bahwa prestasi belajar adalah suatu nilai yang merupakan pengaturan terakhir yang diberikan oleh pengajar sebanding dengan kemajuan atau hasil belajar siswanya selama periode tertentu. Dengan adanya evaluasi ini, tingkat pencapaian dalam mempelajari suatu poin adalah sesuatu yang dinilai untuk menentukan pencapaian belajar seseorang. Hal ini sangat diidentikkan dengan evaluasi teori tentang daya tahan yang menggabungkan 
keunggulan bahan ajar. Siswa yang menguasai materi pembelajaran dengan baik akan memiliki prestasi belajar yang baik, pada umumnya kemandirian berhubungan dengan prestasi belajar.

\section{Pengaruh self-efficacy terhadap prestasi belajar IPS siswa kelas VIII SMP}

\section{Negeri 2 Sumber Kabupaten Cirebon}

Untuk mengetahui pengaruh self-efficacy dan prestasi belajar IPS pada siswa kelas VIII SMP Negeri 2 Sumber Kabupaten Cirebon dilakukan uji teori dengan kekambuhan dasar lurus. Sebelum menghitung uji spekulatif, terlebih dahulu dilakukan uji esensial, khususnya uji ordinaris dan linieritas. Berikut ini adalah hasil dari mengerjakan soal tes biasa dengan menggunakan SPSS form 22.0:

Tabel 1. Output Kenormalan Data

\begin{tabular}{|l|r|r|r|r|r|r|}
\hline \multirow{2}{*}{} & \multicolumn{3}{|c|}{ Kolmogorov-Smirnov $v^{2}$} & \multicolumn{3}{|c|}{ Shapiro-Wilk } \\
\cline { 2 - 8 } & Statistic & \multicolumn{1}{c|}{ Df } & \multicolumn{1}{c|}{ Sig. } & Statistic & \multicolumn{1}{c|}{ Df } & \multicolumn{1}{c|}{ Sig. } \\
\hline Self.Efficacy & .122 & 60 & .052 & .965 & 60 & .084 \\
Prestasi.Belajar & .081 & 60 & $.200^{\circ}$ & .975 & 60 & .248 \\
\hline
\end{tabular}

*. This is a lower bound of the true significance.

a. Lilliefors Significance Correction

Dilihat dari efek samping uji coba keteraturan pada tabel di atas, cenderung terlihat bahwa nilai Sig. di bagian Kolmogorov-Smirnov untuk selfefficacy dan prestasi belajar dipahami bahwa Sig. 0,052 0,05 sehingga menunjukkan bahwa informasi tersebut biasa beredar. Uji banding dua varietas (homogenitas) digunakan untuk menentukan keragaman data hasil tes di SMP Negeri 2 Sumber Kabupaten Cirebon. Berikut hasil dari pengujian homogenitas menggunakan program SPSS 22.0:

Tabel 2. Output Homogenitas Data 


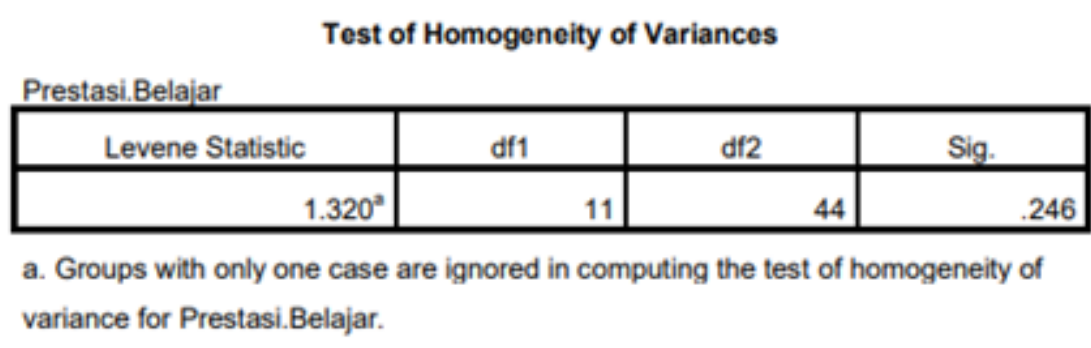

Pada tabel Test of Homogeneity of Variances diperoleh nilai Sig = 0,246. Dalam aturan dinamis dinyatakan bahwa jika dalam Sig. > 0,05 maka seharusnya homogen, dalam hal apapun jika fragmen Sig. $<0,05$ maka informasinya tidak homogen. Berdasarkan tabel Uji Homogenitas Varians di atas, diketahui bahwa Sig. 0,246 > 0,05 sehingga hal ini menunjukkan bahwa data tersebut homogen. Berikut pengujian linearitas, berikut adalah hasil pengujian linearitas dengan menggunakan program SPSS 22.0 :

Tabel 3. Output Linieritas Data

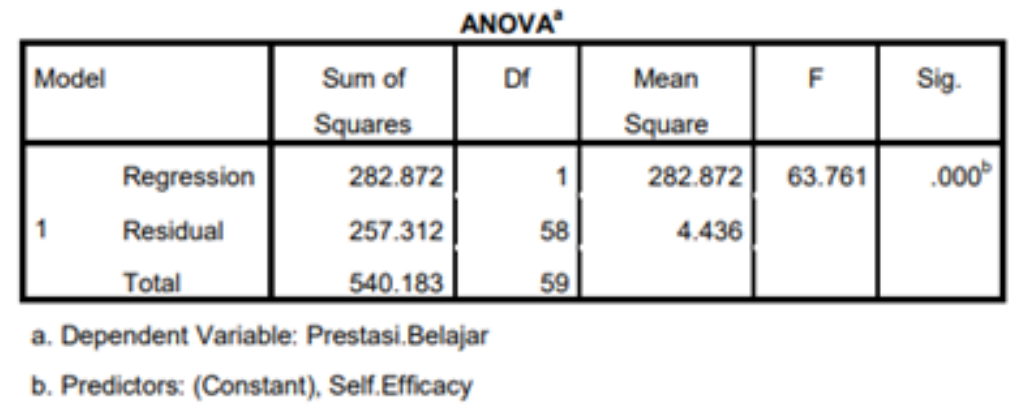

Pada tabel ANOVA diperoleh nilai $\mathrm{F}=63.761$ dengan nilai $\mathrm{Sig}=0,000$. Dalam memutuskan keputusan, dinyatakan bahwa jika dalam Sig. $<$ 0,05 maka informasi tersebut memiliki contoh langsung, tanpa diduga jika Sig. > 0,05 maka informasinya tidak langsung. Berdasarkan tabel ANOVA di atas, dapat dipahami bahwa Sig. 0,000 $<0,05$ sehingga hal ini menunjukkan bahwa informasi tersebut bersifat langsung. Selain itu, konsekuensi dari pengujian spekulasi dapat ditemukan pada tabel berikut:

\section{Tabel 4. Output Hipotesis Data}




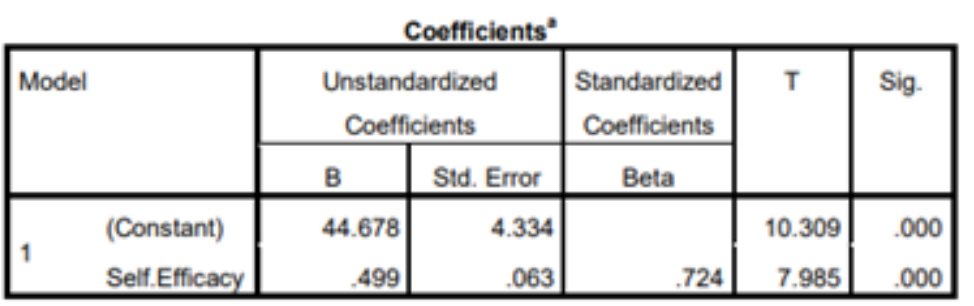

a. Dependent Variable: Prestasi.Belajar

Hasil uji hipotesis pada tabel di atas menunjukkan bahwa terdapat pengaruh positif antara self-efficacy dengan prestasi belajar siswa dengan mendapatkan thitung 7,985 > ttabel 2,001 atau Sig. 0,000<0,05. Dampak positif antara self-efficacy dan prestasi belajar ini sesuai dengan pandangan Zimmerman dalam buku harian yang disusun oleh Mukhid (2009) yang menyatakan bahwa kelangsungan hidup mempengaruhi prestasi langsung dengan memperluas tujuan kelas siswa.

Kepastian karakterisasi pengaruh antara faktor self-efficacy dan prestasi belajar dapat dilihat dengan memanfaatkan penjabaran koefisien koneksi yang diperoleh atau nilai r pada tabel di bawah ini:

Tabel 5. Output Korelasi Data

\begin{tabular}{|ll|r|r|}
\hline \multicolumn{3}{|c|}{ Correlations } \\
\hline & Pearson Correlation & Self.Efficacy & Prestasi.Belajar \\
\hline \multirow{3}{*}{ Self.Efficacy } & Sig. (2-tailed) & 1 & $.724^{* \prime}$ \\
& $\mathrm{N}$ & & .000 \\
& Pearson Correlation & 60 & 60 \\
Prestasi.Belajar & Sig. (2-tailed) & .724 & 1 \\
& $\mathrm{~N}$ & 600 & 60 \\
\hline
\end{tabular}

Seperti yang ditunjukkan oleh Sugiyono (2010) daftar pemahaman koefisien koneksi hubungan antara viabilitas diri dan prestasi belajar IPS siswa kelas VIII SMP Negeri 2 Sumber Kabupaten Cirebon termasuk dalam kelompok tinggi karena hasil estimasi Hubungan item kedua dengan bantuan adaptasi SPSS 22.0 menunjukkan nilai 0,724 , nilai wacana dengan interpretasi menurut Sudijono (2006) berada pada kualitas mencapai antara 0,70 hingga 0,90 dengan citra tingkat hubungan yang solid. Hal ini menunjukkan bahwa 
self-efficacy siswa memiliki hubungan yang nyaman dengan prestasi belajar. Akibatnya, tidak hanya ada dampak positif dan besar antara kedua variabel, tetapi juga hubungan yang solid.

Tabel 6. Output Koefisien Determinasi

\begin{tabular}{|l|r|r|r|r|}
\hline Model & Model Summary \\
\hline & R Square & Adjusted R Square & $\begin{array}{c}\text { Std. Error of the } \\
\text { Estimate }\end{array}$ \\
\hline 1 & $.724^{2}$ & .524 & & 2.10628 \\
\hline
\end{tabular}
a. Predictors: (Constant), Self.Efficacy
b. Dependent Variable: Prestasi.Belajar

Koefisien jaminan yang dapat kita temukan pada tabel di atas menunjukkan sejauh mana self-efficacy terhadap prestasi belajar adalah 52,4\%, sedangkan sisanya $(100 \%-52,4 \%=47,6 \%)$ diperjelas dengan berbagai alasan yang tidak diselidiki. Hal ini menunjukkan bahwa self-efficacy menambah prestasi siswa.

Kondisi kekambuhan dampak self-efficacy terhadap prestasi belajar siswa adalah $=44.678+0.499 \mathrm{X}$. Nilai yang layak sebesar 44.678 menunjukkan bahwa dengan asumsi Anda tidak memiliki self-efficacy dalam mata pelajaran IPS, prestasi siswa dalam mata pelajaran IPS adalah 44.678 dan nilai koefisien sebesar 0,499 menunjukkan bahwa self-efficacy selain satu unit akan meningkatkan prestasi belajar siswa sebesar 0,499 unit. Ukuran tes kekambuhan dapat ditemukan pada tabel terlampir :

Tabel 7. Output Analisis Regresi

\begin{tabular}{|c|c|c|c|c|c|c|}
\hline \multicolumn{7}{|c|}{ Coefficients $^{\circ}$} \\
\hline \multirow{2}{*}{\multicolumn{2}{|c|}{ Model }} & \multicolumn{2}{|c|}{$\begin{array}{l}\text { Unstandardized } \\
\text { Coefficients }\end{array}$} & \multirow{2}{*}{$\begin{array}{c}\text { Standardized } \\
\text { Coefficients } \\
\text { Beta }\end{array}$} & \multirow[t]{2}{*}{ T } & \multirow[t]{2}{*}{ Sig. } \\
\hline & & B & Std. Error & & & \\
\hline \multirow{2}{*}{1} & (Constant) & 44.678 & 4.334 & & 10.309 & .000 \\
\hline & Self.Efficacy & .499 & .063 & .724 & 7.985 & .000 \\
\hline
\end{tabular}

a. Dependent Variable: Prestasi.Belajar 
Seseorang dengan self-efficacy yang tinggi akan sering mengetahui lebih banyak dan mencapai lebih banyak daripada orang dengan kelangsungan hidup rendah. Ini tetap konstan terlepas dari, ketika tingkat batas asli adalah sesuatu yang pada dasarnya sama (Omrod, 2008). Dalam pandangan ini, skor diamati yang secara langsung relatif terhadap self-efficacy dan prestasi belajar. Siswa yang mendapatkan nilai tinggi dalam menyelesaikan skala kompetensi diri juga memiliki rapor yang bagus. Hal ini terlihat dari hasil pengujian hipotesis dalam tinjauan ini yang menyatakan bahwa Ho ditolak dan Ha diakui. Yang diakui dalam tinjauan ini adalah terdapat hubungan yang positif dan mendasar antara kemandirian dengan prestasi belajar IPS pada siswa kelas VIII SMP Negeri 2 Sumber Kabupaten Cirebon.

\section{KESIMPULAN}

Mengingat akibat dari hasil pembahasan di atas yang diidentikkan dengan pengaruh self-efficacy terhadap prestasi belajar, maka cenderung beralasan bahwa self-efficacy siswa SMP Negeri 2 Sumber Kabupaten Cirebon tergolong cukup baik. Hal ini ditunjukkan dengan tercapainya proporsi self-efficacy yang digerakkan oleh siswa sesuai penegasan responden sebesar $69,18 \%$ berada pada cakupan 56-75\%. Secara numerik, pencapaian ini tampaknya tidak terlalu ideal, namun jika dilihat dari keyakinan yang dipegang dengan menggabungkan derajat kesukaran (level), tingkat solidaritas (kekuatan), dan spekulasi (konsensus) dipandang sebagai energi tertentu.

\section{REFERENSI}

Adnyana, \& Purnami. (2016). Pengaruh Pendidikan Kewirausahaan, self-efficacy dan locus of control pada niat berwirausaha. Doctoral Disertation: Udayana University.

Amanda, Subagia, \& Tika. (2014). Pengaruh Model Pembelajaran Berbasis Proyek terhadap Hasil Belajar IPA ditinjau dari Self-efficacy Siswa. Jurnal Pendidikan Dan Pembelajaran IPA Indonesia, 4(1).

Bire, A. L., Geradus, U., \& Bire, J. (2014). Pengaruh Gaya Belajar Visual, Auditorial, dan Kinestetik terhadap Prestasi Belajar Siswa. Jurnal Kependidikan: Penelitian Dan Inovasi Pembelajaran, 44(2). 
Ghufron, M. N., \& Risnawati, R. (2016). Teori-teori Pesikologi. Yogyakarta: ArRuzz Media.

Hardianto, G., Erlamsyah, \& Nurfahanah. (2014). Hubungan Antara Self-efficacy Akademik dengan Hasil Belajar Siswa. Jurnal Konselor, Vol. 3.

Hari, L. V., Zanthy, L. S., \& Hendriana, S. (2018). Pengaruh Self-efficacy terhadap Kemampuan Berpikir Kritis Matematika Siswa SMP. JPMI (Jurnal Pembelajaran Matematika Inovatif), 1(3).

Hulu, T., \& Minauli, I. (2013). Hubungan Antara Kecerdasan Emosi dan Efikasi Diri dengan Prestasi Belajar. Analitika: Jurnal Magizter Psikologi UMA, 5(2).

Janatin, M. (2015). Hubungan antara Self-Efficacy dengan Prestasi Belajar Siswa Kelas IV SD Se-Gugus II Kecamatan Bantul Tahun Ajaran 2014/2015. Jurnal Pendidikan Sains.

Marini, C. ., \& Hamidah, S. (2014). Pengaruh Self-efficacy, Lingkungan Keluarga, dan Lingkungan Sekolah terhadap Minat Berwirausaha Siswa SMK Jasa Boga. Junal Pendidikan Vokasi, 4(2).

Martinez, S. ., \& Stager, G. (2013). Invent to Learn. Making, Tingkering, and Engineering in the Classroom. Torrance, Kanada: Constructing Modern Knowledge.

Mukhid, A. (2009). Self-efficacy (Prespektif Teori Kognitif dan Implikasinya terhadap Pendidikan). Tadris, Volume $4 \mathrm{~N}$.

Omrod, J. E. (2008). Psikologi Pendidikan: Membantu Siswa Tumbuh dan Berkembang. Jakarta: Erlangga.

Pertiwi, N. G. (2015). Pengaruh Self-Efficacy terhadap Hasil Belajar pada Siswa Kelas V Sekolah Dasar Daerah Binaan IV Kecamatan Cilacap Selatan Kabupaten Cilacap. Unnes Repository. http://lib.unnes.ac.id/id/eprint/21060

Pratesi, P. C. (2018). Persepsi Guru PAUD terhadap Faktor-faktor yang Menghambat dalam Melaksanakan Pembelajaran di PAUD Se-Kecamatan Ujan Mas Kabupaten Kepahiang. Raudhatul Athfal: Jurnal Pendidikan Islam Anak Usia Dini, 2(2).

Rijal, S., \& Bachtiar, S. (2015). Hubungan antara Sikap, Kemandirian Belajar, dan Gaya Belajar dengan Hasil Belajar Kognitif Siswa. Jurnal Bioedukatika, 3(2).

Rosyid, M. Z., Mansyur, M., \& Abdullah, A. R. (2019). Prestasi Belajar. Literasi Nusantara.

Rosyida, F., Utaya, S., \& Budijanto, B. (2016). Pengaruh Kebiasaan Belajar dan Self-efficacy terhadap Hasil Belajar Geografi di SMA. Jurnal Pendidikan Geografi, 21(2).

Schmoker, M. (2018). Focus: Elevating the Essentials to Radically Improve Student Learning. Ascd.

Sholichah, I. (2017). Pengaruh Self-Efficacy terhadap Hasil Belajar Matematika Siswa Kelas VII MTs Darussalam Kademangan Blitar Tahun Ajaran 2016/2017. IAIN Tulungagung Institutional Repository. http://repo.iaintulungagung.ac.id/id/eprint/5532

Sirait, E. D. (2016). Pengaruh Minat Belajar terhadap Prestasi Belajar Matematika. Formatif: Jurnal Ilmiah Pendidikan MIPA, 6(1).

Sudijono, A. (2006). Pengantar Evaluasi Pendidikan. Jakarta: Raja Grafindo 
Persada.

Sugiyono. (2010). Metode Penelitian Kuantitatif, Kualitatif dan R\&D. Bandung: Penerbit Alfabeta.

Suryabrata, S. (2002). Psikologi Pendidikan. Jakarta: Raja Grafindo Persada.

Wijayani, I., Budi, E., \& Sugiman, S. (2017). Hubungan Motivasi Belajar dengan Prestasi Belajar Siswa Kelas V. Pedagogi: Jurnal Pendidikan Dasar, 5(16).

Yoannita, B., Budi, E., \& Rustana, C. E. (2016). Pengaruh Self-efficacy terhadap Hasil Belajar Fisika melalui Penggunaan Model Problem Based Learning. Prosiding Seminar Nasional Fisika (E-Jurnal), Vol. 5, pp. 